\title{
In vitro propagation and conservation of Leontopodium palibinianum Beauverd (Asteraceae), endemic species of Primorye Territory
}

\author{
A. S. Pianova (Berdasova) $)^{1,2 *}$, A. V. Salokhin ${ }^{1,3}$, Yu. E. Sabutski ${ }^{1,4}$ \\ ${ }^{1}$ Botanical Garden-institute FEB RAS, Makovskii Str., 142, Vladivostok, 690024, Russian Federation \\ 2E-mail: berdasova_as@mail.ru; ORCIDiD: http://orcid.org/0000-0002-7344-7589 \\ ${ }^{3}$ ORCID iD: https://orcid.org/0000-0002-4902-8472 \\ ${ }^{4}$ ORCID iD: https://orcid.org/0000-0003-3815-6142 \\ *Corresponding author
}

Keywords: endemic species, microclonal propagation, Palibin's edelweiss, rare species, rooting in vitro.

Summary. The microclonal propagation protocol including initiation, propagation, rootage, and adaptation in the premises of the Botanical Garden-Institute FEB RAS was developed for the first time for a vulnerable endemic species of Primorye Territory Leontopodium palibinianum (Palibin's edelweiss). It was shown that the medium's mineral composition as well as changes in the concentration of exogenous growth regulators under the same light and temperature conditions had a substantial impact the processes of growth and morphogenesis of Palibin's edelweiss. Optimal components of the microclonal propagation medium of the species were full strength Murashige and Skoog medium. Reducing in the salt amount leads to a slowdown and arrest of in vitro culture growth. Adding $2 \mathrm{mg} / \mathrm{l}$ of 6-BAP to the full strength MS medium led to mass production of plant material with the propagation factor of 9.8. It should be noted that $\mathrm{GK}_{3}$ has a positive effect on the Palibin's edelweiss culture development in vitro when used together with low concentrations of 6-BAP. When 2.4-D was used at the concentration of $1 \mathrm{mg} / 1$ in the medium, direct organogenesis was observed after 14 days of cultivation and further accompanied by formation of additional plant shoots. Also, addition of $1 \mathrm{mg} / \mathrm{l} 2 \mathrm{iP}$ to the MS medium had the same effect. The growth regulators caused a low propagation factor (2.4), which in turn led to production of 2-3 regenerative plants. The IBA concentration of $2 \mathrm{mg} / \mathrm{l}$ stimulated formation of the root system capable of positively withstanding acclimatization under unsterile conditions, but lowering the IBA concentration to $1 \mathrm{mg} / \mathrm{L}$ of the medium also contributed to formation of such root system, with a slower pace. During acclimatization to ex vitro conditions plant survival did not depend on the types of mixtures being used. After the acclimatization plants are stretched in height and produced additional shoots on 20-25th day.

\section{Размножение и сохранение в культуре in vitro Leontopodium palibinianum Beauverd (Asteraceae) - эндемика Приморского края}

\author{
А. С. Пьянова (Бердасова), А. В. Салохин, Ю. Е. Сабуцкий \\ Ботанический сад-институт ДВО РАН, ул. Маковского, 142, г. Владивосток, 690024, Россия
} Ключевые слова: микроклональное размножение, редкие виды, укоренение in vitro, эдельвейс Палибина,
эндемичные виды.

Аннотация. Впервые разработан протокол микроклонального размножения уязвимого вида, эндемика Приморского края, Leontopodium palibinianum (эдельвейс Палибина), включающий введение в культуру, размножение, укоренение и адаптацию на базе Ботанического сада-института ДВО РАН. Показано, что минераль- 
ный состав среды при одних и тех же световых и температурных режимах, а также изменение концентрации экзогенных регуляторов роста существенно влияют на процессы роста и морфогенеза эдельвейса Палибина. Оптимальными компонентами среды для микроклонального размножения изучаемого вида являются полные составы солей по прописи Мурасиге-Скуга, уменьшение количества солей приводит к замедлению и остановке роста культуры in vitro. Добавление в среду МС с полным составом солей 2 мг/л 6-БАП приводит к массовому получению растительного материала с коэффициентом размножения 9,8. Следует отметить положительное влияние на развитие культуры в условиях in vitro ГК $_{3}$ при совместном применении с низкими концентрациями 6-БАП. При использовании 2,4-Д в концентрации 1 мг/л среды спустя 14 дней культивирования наблюдали прямой органогенез, который в дальнейшем сопровождался образованием дополнительных побегов у растений, такое же влияние оказывало добавление в среду МС 1 мг/л 2іР. При использовании данных регуляторов роста мы отмечали низкий коэффициент размножения $(2,4)$, приводящий к получению 2-3 растений-регенерантов. Эффективное образование корневой системы, способной положительно перенести акклиматизацию в нестерильных условиях происходило при использовании ИБК в концентрации 2 мг/л. Снижение концентрации ИМК до 1 мг/л также способствовало корнеобразованию, но с более медленной скоростью. При акклиматизации к условиям ex vitro приживаемость растений не зависела от используемых типов смесей. После акклиматизации растения вытягивались в высоту и давали дополнительные побеги на 20-25 сутки.

\section{Introduction}

Genus Leontopodium R. Br. ex Cass. includes more than 30 species distributed in mountainous regions of Eurasia and South America. Eleven species of the genus grow in the Russian Far East. L. palibinianum Beauverd (Palibin's edelweiss) is perennial herbaceous plant with height of up to 35 $\mathrm{cm}$, and also with a branched rhizome and fibrous roots. Its greyish or greenish tomentose pubescent stems are 1 to $6 \mathrm{~cm}$ long. The radical leaves are lanceolate-elliptic, up to $7 \mathrm{~cm}$ long, greenish spidery pubescent in the top and white pubescent in the bottom. The cauline leaves are up to $6 \mathrm{~cm}$ long and up to $10 \mathrm{~mm}$ wide. The bracteal leaves are 5 to $10 \mathrm{~cm}$, densely white tomentose, less often with a greenish or yellowish tint, forming a large, almost regular star of 4-9 cm diameter. The anthodes are hemispherical from 4 to 11 . The distribution area of L. palibinianum is limited to the sea coast. It is an endemic nemoral species distributed in the eastern macroslopes of Sikhote-Alin, which grows in coastal meadows outside the active salinization area, in rock clefts and on gravelly slopes, while being more numerous on limestone outcrops and occasionally distributed in supralittoral zone. It is protected in the Sikhote-Alin and Lazov Reserves (Galanin et al., 2004; Kozhevnikov, Kozhevnikova, 2012; Pimenova et al., 2016; Kozhevnikov et al., 2019). This species is also reported in Nakhodka Municipal District (Prokopenko, Nechayev, 2016) and the Kavalerovo District (Pospelova et al., 2019). The Palibin's edelweiss is registered in the Red Data Book of Primorsky region (plants) and has the status of vulnerable endemic species (Barkalov, 2008). L. palibinianum is considered to be one of the most decorative edelweiss in Russia.
The data available on attempts to introduce of Palibin's edelweiss by traditional methods are quite scarce. For instance, S. K. Malysheva published the results of introduction of L. palibinianum in the V. L. Komarov Gornotayozhnaya Station. However, the results of that experiment turned out to be unsuccessful (Malysheva, 2018). Attempts to introduce L. palibinianum also were made in the Botanical Garden-Institute FEB RAS, but the plant's life did not exceed three years and after that period it died (personal message from V. A. Kalinkina). Of all representatives of genus Leontopodium only L. nivale (Ten.) Heut ex Hand.-Mazz. (Pace, 2009; Wawrosch et al., 2014), L. alpinum Cass. (Hook, 1993; Zapartan, 1996; Lulli et al., 2012; Wawrosch et al., 2014) and $L$. coreanum Nakai (Park et al., 1987) were introduced. Data on microclonal propagation of Palibin's edelweiss was obtained for the first time and the microclonal propagation protocol for L. palibinianum was also developed. Viable callus tissue was obtained and the plants were regenerated. The obtained plants could serve as material for further introduction into outdoor planting.

\section{Materials}

\section{Objects}

1. Mature seeds of L. palibinianum.

2. Sprouts and parts of the plants produced in vitro.

Reagents

1. Macro- and microelements, as well as vitamins of Murashige and Skoog medium (Murashige, Skoog, 1962).

2. Agar (Sigma-Aldrich, USA).

3. 2/4-dichlorophenoxyacetic acid, 2.4-D (SigmaAldrich, USA). 
4. N6-benzylaminopurine, 6-BAP (SigmaAldrich, USA).

5. Indolyl-3-butyric acid, IBA (BioReagent, SigmaAldrich, USA).

6. Gibberelinic acid, $\mathrm{GA}_{3}$ (BioReagent, SigmaAldrich, USA).

7. N6-(2-isopentenyl)-adenine, 2iP (BioReagent, SigmaAldrich, USA).

8. Sucrose (Helicon, Russia).

Equipment

1. Constant climate chamber KBF 720 (Binder, Germany).

Procedures

\section{Culture medium}

1. In all experiments, $0.7 \%$ agarized Murashige and Skoog (MS) medium with $3 \%$ sucrose was used.

2. The medium's $\mathrm{pH}$ was adjusted with $\mathrm{HCl}$ solution to 5.6-5.8 before autoclaving.

3. Autoclaving was carried out at $121{ }^{\circ} \mathrm{C}, 1$ atmosphere for $20 \mathrm{~min}$. Growth regulators were added to the medium after autoclaving.

\section{Sterilization and planting of seeds.}

1. The seeds were washed with chlorhexidine 3 times for $10 \mathrm{~min}$. each time, and then with distilled water.
2. They were sterilized with $1 \%$ silver nitrate and washed three times with sterile distilled water.

3. They were then placed onto hormone-free MS culture medium and incubated in a refrigerated chamber at $5 \pm 1^{\circ} \mathrm{C}$ for 30 days to stimulate germination.

4. After 30 days, the test tubes were transferred to the constant climate chamber maintaining a constant temperature of $17 \pm 1^{\circ} \mathrm{C}$ for germination.

5. After germination, cultivation was carried out in a room under white fluorescent light bulbs (Philips, Poland) with the illuminance of 2000 to 3000 lux illumination with the light/dark photoperiod of $16 / 8 \mathrm{~h}$ at $23 \pm 2{ }^{\circ} \mathrm{C}$.

\section{Preparation of explants}

1. After 12 days of cultivation in light, the sprouts were transferred to the test tubes containing the MS medium without adding growth regulators.

\section{Induction of organogenesis}

1. Explants from the produced plants were placed onto the surface of MS culture medium with the addition of growth regulators of various concentrations (see Table).

2. After 21 days of cultivation, the morphogenetic response was assessed. If necessary, the observations were continued.

Table

Culture medium options

\begin{tabular}{|c|c|c|c|c|c|c|c|}
\hline \multirow{2}{*}{$\begin{array}{c}\text { No. of } \\
\text { experience }\end{array}$} & \multirow[t]{2}{*}{ Mineral composition } & \multicolumn{5}{|c|}{ Content of growth regulators, $\mathrm{mg} / \mathrm{L}$} & \multirow{2}{*}{$\begin{array}{l}\text { Propagation } \\
\text { factor }\end{array}$} \\
\hline & & 2.4-D & 6-BAP & $2 \mathrm{iP}$ & IBA & $\mathrm{GA}_{3}$ & \\
\hline 1 & MS & 1 & - & - & - & - & 2.4 \\
\hline 2 & MS & - & 1 & - & - & - & 5.0 \\
\hline 3 & MS & - & 2 & - & - & - & 9.8 \\
\hline 4 & MS & - & 0.5 & - & - & - & 2.8 \\
\hline 5 & $1 / 2 \mathrm{MS}$ & - & 1 & - & - & - & 0 \\
\hline 6 & $1 / 4 \mathrm{MS}$ & - & 1 & - & - & - & 0 \\
\hline 7 & MS & - & - & 1 & - & - & 2.4 \\
\hline 8 & $1 / 2 \mathrm{MS}$ & - & - & 1 & - & - & 0 \\
\hline 9 & $1 / 4 \mathrm{MS}$ & - & - & 1 & - & - & 0 \\
\hline 10 & $1 / 2 \mathrm{MS}$ & - & - & - & 0.5 & - & 0 \\
\hline 11 & MS & - & - & - & 1 & - & 1.4 \\
\hline 12 & MS & - & - & - & 2 & - & 1.4 \\
\hline 13 & MS & - & - & - & - & 1 & 1.6 \\
\hline 14 & MS & - & 0.25 & - & - & 1 & 2.4 \\
\hline 15 & MS (control) & - & - & - & - & & 2.0 \\
\hline
\end{tabular}


Acclimatization of plants to aseptic conditions

1. The rooted plants were adapted to the soil by sowing onto sterile vermiculite and a mixture of vermiculite and perlite at 1:1 ratio, as well as into a sterile mixture of $2 / 4$ peat, $1 / 4$ vermiculite and $1 / 4$ of crushed decayed birch wood.

2. The containers were covered with polyethylene bags to maintain humidity and placed under LED lights.

3. Irrigation was carried out at room temperature water as the soil dried.

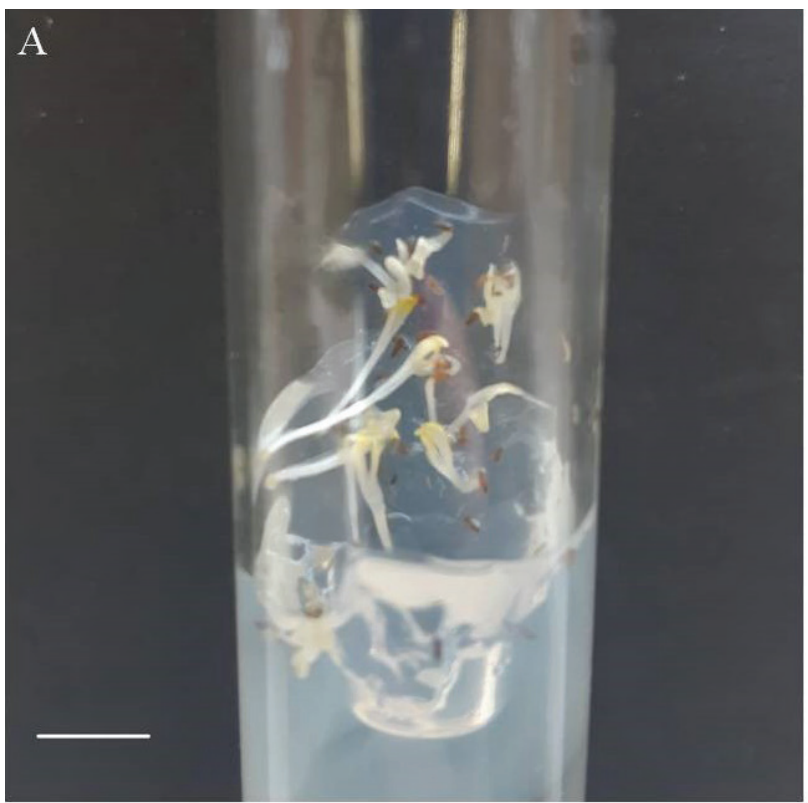

\section{Conclusion}

The first sprouts were registered on the 4th day of cultivation in the constant climate in climatic chamber at $17 \pm 1{ }^{\circ} \mathrm{C}$ (Fig. 1). All sprouts were viable and produced additional shoots, which served as material for further study of the impact of various growth regulators on morpho- and rhizogenesis of L. palibinianum in the in vitro environment.

Fig. 1. The sprouts emerged during cultivation in the constant climate chamber (A) and after 12 days of cultivation in light (B). Ruler interval: $1 \mathrm{~cm}$.
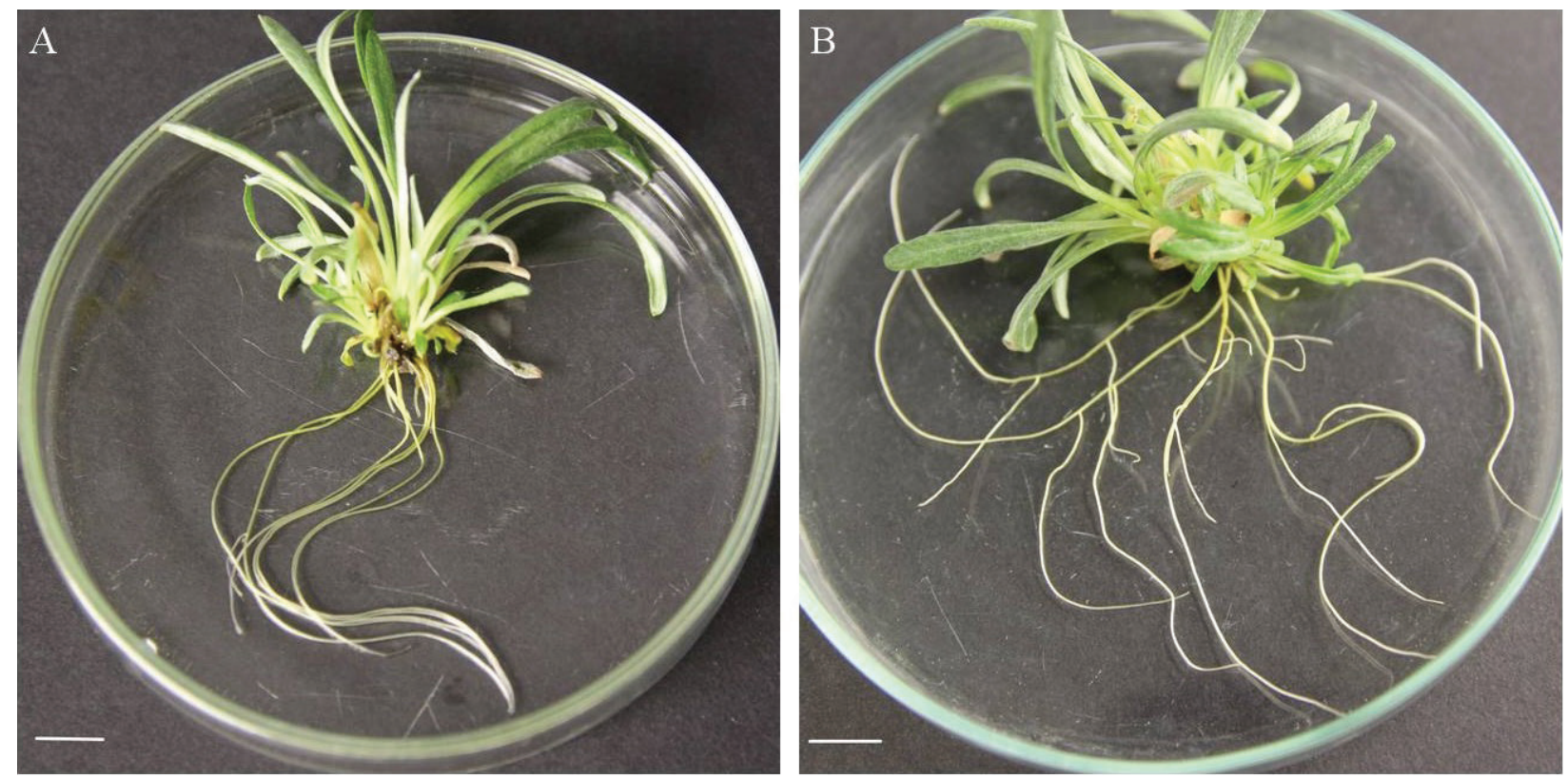

Fig. 2. Root system on the $21 \mathrm{st}$ day of cultivation after emergence of the first routes at the IBA concentrations of $1 \mathrm{mg} / \mathrm{l}$ (A) and $2 \mathrm{mg} / \mathrm{l}(\mathrm{B})$. Ruler interval: $1 \mathrm{~cm}$. 
The main factor during the microclonal propagation of Palibin's edelweiss is the concentration of the culture medium' mineral base (MS, $1 / 2 \mathrm{MS}$ and $1 / 4 \mathrm{MS}$ ), as well as exogenous growth regulators. It was found that reduction in the concentration of Murashige and Skoog medium's macrosalts to $1 / 2$ MS resulted in slowed growth without formation of additional shoots, so this protocol could be used to maintain L. palibinianum in vitro. During further reduction of macronutrients to $1 / 4 \mathrm{MS}$, tissue necrosis on the 16th day of cultivation and their further death were observed, what was apparently associated with a lack of macronutrients, despite the presence of 6-BAP and 2iP hormones at $1 \mathrm{mg} / 1$ concentration.

The exogenous growth regulator 6-BAP plays a significant role in regulating the in vitro organogenesis of L. palibinianum. For instance, when the concentration of this growth regulator was increased to $2 \mathrm{mg} / \mathrm{l}$, we observed the highest propagation factor (see Table) with formation of up to 12 new additional shoots from a single initial explant.

The direct organogenesis was observed after 14 days of cultivation when using 2.4-D at the concentration of $1 \mathrm{mg} / \mathrm{l}$ of the medium and accompanied by the formation of additional plant shoots. Addition of $1 \mathrm{mg} / \mathrm{L} 2 \mathrm{iP}$ to the MS medium had the same effect. Using these growth regulators, we obtained only 2-3 new clones. It should also be noted that the formation of additional shoots in L. palibinianum also occurred during cultivation on a medium with IBA (see Table), which was not previously described for edelweiss. Thus, the most effective micropropagation occurred on the full strength MS medium with addition of 6 -BAP at $\mathrm{mg} / \mathrm{l}$ concentration.

Also we used regulators to stimulate stem insertion growth and root formation. For instance, addition of $1 \mathrm{mg} / \mathrm{l} \mathrm{GA}$ to the medium contributed to elongation of the shoots, while supplementing the medium with the hormone in combination with 0.25 $\mathrm{mg} / \mathrm{l}$ of 6-BAP resulted in formation of the longest and largest leaves. The IBA concentration had an impact not only on the number, but also on the size of the roots formed. The maximum size and larger number of roots were observed during cultivation on the medium with complete mineral composition and use of $2 \mathrm{mg} / \mathrm{L}$ of IBA (Fig. 2), while the first roots were observed as early as on the 7th day of cultivation. Decrease in the IBA concentration to $1 \mathrm{mg} / 1$ contributed to slow-down of these processes (Fig. 2 ), where formation of the first roots was recorded on 21st day of cultivation, but their number after a longer period of time was equal or almost equal to that at the previous concentration. Decreasing the IBA concentration to $0.5 \mathrm{mg} / 1$ did not produce positive results, root formation wasn't observed, though this may also be due to the fact that at this concentration the number of macroelements in the basic medium was reduced as well.

Based on the previously obtained results on preservation of rare species in vitro (Kritskaya, Kashin, 2016; Molkanova et al., 2016), part of the L. palibinianum collection in the form live plants in flasks was placed in the lower temperature environment $\left(5 \pm 1{ }^{\circ} \mathrm{C}\right)$ for long-term deposition. After 120 days of storage of plant vessels at lower temperature we successfully obtained explants and regenerated plants from them under normal conditions.

After 20-25 days of cultivation in containers with soil, the plants produce additional shoots and stretched in height. The plants' survival rate did not depend of the type of mixture.

This study could help introduce L. palibinianum into outdoor planting, as well as contribute to the conservation of natural populations of this unique plant of the Russian Far East.

\section{Acknowledgments}

The study was conducted using a unique scientific facility "Collection of in vitro live plants of the Botanical Garden-Institute FEB RAS" under scientific and research topic "Ex situ and in vitro introduction and conservation of genetic plant resources of East Asia" No. AAAA-A20-120040890002-8.

\section{REFERENCES / ЛИTEPATУРA}

Barkalov V. Yu. 2008. Leontopodium palibinianum (Beauv.) In: Krasnaya kniga Primirskogo kraya: Rasteniya [Red Data Book of Primorsky krai. Rare and endangered species of plants]. Vladivostok: AVK «Apelsin». P. 325. [In Russian] (Баркалов В. Ю. Эдельвейс Палибина - Leontopodium palibinianum (Beauv.) // Красная книга Приморского края: Растения. Редкие и находящиеся под угрозой исчезновения виды растений и грибов. Владивосток: АВК «Апельсин», 2008. С. 325).

Galanin A. V., Averkova G. P., Barkalov V. Yu., Bezdeleva T. A., Belikovich A. V., Vasilenko N. A., Galanina I. A., Kozhevnikov A. Ye., Mihaleva N. A., Nedeluzhko V. A., Nesterova I. A., Pavlova N. S., Pimenova E. A., Probatova N. S., Smirnova E. A., Yakubov V. V. 2004. Flora Sikhote-alinskogo biosfernogo zapovednika (sosudistyye rasteniya) [Flora of the Sikhote-Alin Biosphere Reserve (vascular plants)]. Vladivostok: BSI DVO RAN. 301 pp. [In Russian] 
(Галанин А. В., Аверкова Г. П., Баркалов В. Ю., Безделева Т. А., Беликович А. В., Василенко Н. А., Галанина И. А., Кожевников А. Е., Михалева Н. А., Недолужко В. А., Нестерова И. А., Павлова Н. С., Пименова E. A., Пробатова Н. C., Смирнова $\boldsymbol{E}$. A., Якубов В. В. Флора Сихотэ-Алинского биосферного заповедника (сосудистые растения). Владивосток: БСИ ДВО РАН, 2004. 301 с.).

Hook I. L. I. 1993. Leontopodium alpinum Cass. (Edelweiss): In vitro culture, micropropagation, and the production of secondary metabolites. In: Medicinal and Aromatic Plants. IV. Y. P. S. Bajaj (Ed.) Biotechnology in agriculture and forestry 21: 217-232.

Kozhevnikov A. E., Kozhevnikova Z. V. 2012. Taxonomic composition and features of the flora of state natural reserves in the Primorsky Krai. Komarovskiye chteniya [V. L. Komarov Memorial Lectures] 39: 76-126. [In Russian] (Кожевников A. Е., Кожевникова 3. В. Таксономический состав и особенности флоры государственных природных заповедников Приморского края // Комаровские чтения, 2012. № 39. С. 76-126).

Kozhevnikov A. E., Kozhevnikova Z. V., Kwak M., Lee B. Y. 2019. Illustrated flora of the Primorsky Territory (Russian Far East). National Institute of Biological Resources, Incheon. P. 225.

Kritskaya T. A., Kashin A. S. 2016. Features of in vitro cold storage of some of rare and endangered plants of Saratov Region. Izvestiya of Saratov university. New series. Series: Chemistry. Biology. Ecology 16, 1: 74-80. [In Russian] (Крицкая T. A., Кашин A. C. Особенности длительного депонирования культуры in vitro некоторых редких и исчезающих видов растений Саратовской области // Изв. Сарат. ун-та. Нов. сер. Сер. Химия. Биология. Экология, 2016. Т. 16, № 1. С. 74-80). DOI: 10.18500/1816-9775-2016-16-1-74-80

Lulli D., Potapovich A., Riccardo M., Dellambra E., Pressi G., Kostyuk V., Dal T. R., De L. C., Pastore S., Korkina L. 2012. Anti-inflammatory effects of concentrated ethanol extracts of edelweiss (Leontopodium alpinum Cass.) callus cultures towards human keratinocytes and endothelial cells. Mediators of Inflammation 2012: 12. DOI: $10.1155 / 2012 / 498373$

Malysheva S. K. 2018. Negative results of the introduction experiment in the arboretum of Gornotayezhaya station of the FEB RAS. Scientific Journal of Kub SAU 08(142): 18-25. [In Russian] (Малышева С. К. Отрицательные результаты интродуционного эксперимента в дендрарии горнотаежной станции ДВО РАН // Научный журнал КубГАУ, 2018. № 08(142). С. 18-25. DOI: 10.21515/1990-4665-142-011

Molkanova O. I., Konovalova L. N., Stakheyeva T. S. 2016. Propagation and conservation characteristics of valuable and rare species collection in vitro. Bull. of the State Nikit. Botan. Gard. 120: 17-23. [In Russian] (Молканова О. И., Коновалова Л. Н., Стахеева Т. С. Особенности размножения и сохранения коллекции ценных и редких видов растений в условиях in vitro // Бюллетень ГНБС, 2016. № 120. С. 17-23).

Murashige T., Skoog F. 1962. A revised medium for rapid growth and bioassays with tobacco tissue culture. Physiol. Plant 15(13): 473-497.

Pace L. G., Bruno A. A. and Spano L. 2009. In vitro plant regeneration and clonal micropropagation of Leontopodium nivale (Ten.) Heut ex Hand.-Mazz. (Asteraceae). Plant Biosystems 143: 3, 12-16.

Park J. I., Shim S. Y., Kim J. H., Lee B. C., Moon H. K. 1987. In vitro rapid propagation of edelweiss Leontopodium coreanum. Res Rep Inst Genet. 22: 128-131.

Pimenova Ye. A., Medvedeva L. A., Cherdantseva V. Ya., Bulakh Ye. M., Bukharova N. V., Bogacheva A.V., Egorova L. N., Skirina I. F., Malysheva V. F., Malysheva Ye. F., Morozova O. V., Gromyko M. N., Abramova K. G., Gracheva R. G., Rebriyev Yu. A., Svetasheva T. Yu. 2016. Rasteniya, griby i lishayniki Sikhote-alinskogo zapovednika [Plants, fungi and liches of the Sikhote-Alin Reserve]. Vladivostok: Dalnauka. 557 pp. [In Russian] (Пименовa Е. А., Медведева Л. А., Черданцева В. Я., Булах Е. М., Бухарова Н. В., Богачева А. В., Егорова Л. Н., Скирина И. Ф., Малышева В. Ф., Малышева Е. Ф., Морозова О. В., Громыко М. Н., Абрамова К. Г., Грачева Р. Г., Ребриев Ю. А., Светашева Т. Ю. Растения, грибы и лишайники Сихотэ-Алинского заповедника. Владивосток: Дальнаука, 2016. 557 с.).

Pospelova Ye. B., Prokopenko S. V., Kudryavtseva Ye. P. 2019. Flora of the Kavalerovsky district of the Primorye territory. Komarovskiye chteniya [V. L. Komarov Memorial Lectures] 67: 54-164. [In Russian] (Поспелова Е. Б., Прокопенко С. В., Кудрявцева $\boldsymbol{E}$. П. Флора Ковалеровского района Приморского края // Комаровские чтения, 2019. № 67. C. 54-164). DOI: 10.25221/k1.67.3

Prokopenko S. V., Nechaev V.A. 2016. Vascular plants of Nakhodka city district included in the Red Data Books of Russia and Primorye Territory. Biota i sreda zapovednikov Dalnego Vostoka [Biota and environment of nature reserves of the Far East] 2, 9: 64-91. [In Russian] (Прокопенко С. В., Нечаев В. А. Сосудистые растения Находкинского городского округа, включенные в Красные книги России и Приморского края // Биота и среда заповедников Дальнего Востока, 2016. Т. 2, № 9. С. 64-91).

Wawrosch C., Schwaiger S., Stuppner H., Kopp B. 2014. Lignan formation in hairy root cultures of edelweiss (Leontopodium nivale ssp. alpinum (Cass.) Greuter). Fitoterapia 97: 219-223.

Zapartan M. 1996. Conservation of Leontopodium alpinum using in vitro techniques in Romania. Botanic Gardens Micropropogation News 2: 26-29. 